\title{
South Africa in Africa: a case of high expectations for peace
}

\author{
Hussein Solomon*
}

\author{
Department of Political Sciences, University of Pretoria, South Africa
}

\begin{abstract}
This article examines South Africa's engagement with the rest of the African continent in the realm of peace and security since 1994. It notes that despite expectations from the international community as well as its own policy documents that South Africa would promote human rights on the continent, this has not occurred in a substantial manner. Pretoria has been naïve in its mediation attempts, or worse. Pretoria's ambiguous position in relation to human rights is not only a product of domestic variables but also its own lack of capacity, especially on the military front. These domestic constraints are reinforced at a regional level where structures like the African Standby Forces are little more than 'paper tigers'. This serves to reinforce the status quo, ultimately undermining human security and escalating prospects for future conflict. At the same time the article does point to some positive developments arising from the Zuma administration in its engagement on the African continent in its efforts to secure human security for Africa's citizens.
\end{abstract}

Keywords: South Africa; foreign policy; African Union; Southern African Development Community; conflict resolution; mediation; peace; security

'Because the world is a more dangerous place, the international community dare not relinquish its commitment to human rights. This appeal also has a special significance for South Africa. The anti-apartheid campaign was the most important human rights crusade of the post-World War II era. Its success was a demonstration, in my opinion, of the oneness of our common humanity: in these troubled times, its passion should not be lost. Consequently, South Africa will not be indifferent to the rights of others. Human rights will be the light that guides our foreign affairs.'

Nelson Mandela, Former President of South Africa and Nobel Peace Prize Laureate $-1993^{1}$

'Because of its glorious history, the position of the ANC government in South Africa, support of the crimes the Sudanese government continues to commit in Darfur, disturbs the victims of this tragedy more than the positions of China, Egypt, Algeria, Russia and other friends of Sudan. External observers too could easily point out that if Africans themselves don't give a hang about African victims of the Darfur tragedy, why should the rest of the world care?'

Abdelbagi Jibril, Executive Director of the Darfur Relief and Documentation Centre $-2008^{2}$ 


\section{Introduction}

The expectation of many external actors that post-apartheid South Africa would play a prominent role on the African continent, serving as a catalyst for economic growth, democratic values and political stability, existed at the very moment of the country's first democratic elections in 1994. Angela King, the Head of the United Nations Observer Mission in South Africa (UNOMSA) stated, '... this country [South Africa] will soon become a catalyst for the rapid development of not only the southern African region but the rest of the continent. ${ }^{3}$ That these expectations were also shared by South Africa's political elite is also seen in the quotation from former president, Nelson Mandela, at the start of this paper. In part, these expectations were shaped by two factors - the size of South Africa's economy, and its triumphant and peaceful transition away from its apartheid legacy.

The gigantism of South Africa in relation to the rest of Africa is reflected in the fact that the country has a gross domestic product (GDP) which, at \$277 billion, 'represents 25 percent of the total for Africa and one-third of sub-Saharan Africa's economy'. ${ }^{4}$ It should be noted in this context that while Nigeria has the second largest economy on the continent with a GDP of \$207 billion, it remains a singlecommodity economy, with its leaders preoccupied by significant and continued political turmoil within. Implicit here, for the many with great expectations of South Africa, is the idea that the gigantism of South Africa makes this country a natural leader on the continent. And with leadership, comes the responsibility to ensure economic growth and political stability.

The second factor shaping expectations is the way in which South Africa overcame its apartheid legacy, imbuing democratic South Africa with a morally prominent position that necessitates a principled stance against human rights abusers. Expectations were that it would become a source of human security for Africa's long-suffering masses. ${ }^{5}$

What is abundantly clear is that these expectations were largely shared by the ruling African National Congress (ANC) as they swept to power in 1994. Former President Nelson Mandela, in a celebrated 1993 article in Foreign Affairs, ${ }^{6}$ clearly enunciated the pillars of a democratic South Africa's foreign policy. These pillars included the promotion of democracy, human rights, respect for international law and the quest for peace. This was reaffirmed in 2008 by the Director-General of Foreign Affairs, Dr Ayanda Ntsaluba, when he stated that South Africa aimed to promote peace, human rights and democracy on the African continent. ${ }^{7}$ The importance of securing peace and security on this troubled continent was underlined in a report by Khabele Matlosa, ${ }^{8}$ who grimly stated that in 2005 , 'Of the 53 members of the African Union, only six - Botswana; Mauritius; Malawi; Namibia; Tanzania and post-apartheid South Africa - have been spared from civil strife and civil war.'

Over the last 15 years, South Africa has indeed been involved in peace initiatives across the length and breadth of Africa. Pretoria has aimed to broker peace talks in Angola, Burundi, the Democratic Republic of Congo (DRC), Ivory Coast, Lesotho, Kenya, Mozambique, Sierra Leone, Sudan and Zimbabwe. ${ }^{9}$ Moreover, South African peacekeepers have found themselves in Burundi, in the DRC, on the border between Ethiopia and Eritrea and in Darfur, Sudan. South Africa is one of the five largest financial contributors to the African Union (AU). It is South Africa that plays a key role in the proposed African Standby Force (ASF) and especially in its southern African brigade (SADCBRIG). ${ }^{10}$ It is South Africa that is serving a second 
time on the Peace and Security Council of the African Union. It was former President Thabo Mbeki, together with then Nigerian President Olusegun Obasanjo and Senegalese President Abdoulaye Wade who jointly drew up the New Partnership for Africa's Development (NEPAD) framework which sought to place obligations on African leaders to adopt good governance and root out corruption. It is also South Africa that houses the Pan African Parliament (PAP) as well as the NEPAD Secretariat (which has been incorporated as a part of the AU). ${ }^{11}$

These are all laudable initiatives. However, it should also be clear to any dispassionate observer that South Africa has been less than successful in bringing resolution in several cases on the continent. This may not be a reasonable expectation. However, in some cases it could well be argued that South Africa has become an obstacle to peace and security on the African continent.

This paper will not aspire to a comprehensive review of each and every aspect of Pretoria's post-1994 foreign policy over the vast terrain of peace and security on the African continent. Rather, this paper will focus on key areas in which South Africa has failed even reasonable expectations, and suggest ways to rectify this in the postMbeki era. These recommendations include re-examining South Africa's mediation strategies; refocusing security policy around human rights as the cornerstone of sustainable African security; approaching peace-building holistically; and finally, efforts to strengthen South African and African security forces. As this paper will make clear, South African approaches to mediation are fundamentally flawed. Moreover, such poor efforts at peace-making are complemented by a poor regional peace and security architecture which merely serves to reinforce the status quo - the security of Africa's political elites, not its citizens.

\section{Injudiciously projecting the South African experience}

South Africa's democratic transition was an amazing process that managed to still the doomsayers which included Lord Carrington and Henry Kissinger, both of whom expected a bloodbath in South Africa. The Kempton Park negotiating process was inclusive and was characterised by compromise. Zero-sum games were jettisoned in favour of mini-max strategies where victory could be claimed by all. For this reason, South Africa's political transformation is a useful case study for policymakers and scholars to explore and analyse as they confront other conflict situations. That being said, it is also true that this country's democratic transition cannot simply be transplanted onto any other country, least of all where different conditions exist.

Whether the Democratic Republic of the Congo, Angola or Zimbabwe, Pretoria's policymakers have achieved only failure when trying to implement the Kempton Park process in other national contexts. In the Congo the war is ongoing in the eastern Kivu provinces whereas in the centre, Joseph Kabila's government is displaying a worrisome authoritarian streak. In Angola, meanwhile, the civil war ended with the military defeat of the rebel National Union for the Total Independence of Angola (UNITA) movements and the killing of its leader Jonas Savimbi. As for Zimbabwe, the current problems facing the Government of National Unity suggest that Robert Mugabe's ZANU-PF has no understanding of concepts like compromise, which was the hallmark of the Kempton Park peace process. 


\title{
In the DRC
}

Pretoria's involvement in the Great Lakes region began in 1997 when it became clear that the Alliance of Democratic Forces for the Liberation of Congo-Zaire (AFDL) under the leadership of Laurent Kabila was on the military offensive with President Mobutu Sese Seko's Presidential Guard in retreat and his power base crumbling. In Pretoria, as in several regional and international capitals, concern about the spillover effects for neighbouring countries of the disintegration of the Zairian state led to a recognition of the need for an orderly transition to a post-Mobutu era in Zaire. Pretoria, under President Mandela's leadership, immediately responded to this situation by attempting to mediate between President Mobutu and Laurent Kabila. However, this attempt at preventive diplomacy ended in failure for South Africa's diplomats when both parties rejected a negotiated settlement. Why was this so? As Pretoria attempted to negotiate a peace agreement between Mobutu and Kabila, it looked at the situation in Zaire through lenses tainted by its own Kempton Park negotiation process. Mahmood Mamdani ${ }^{12}$ later succinctly commented on developments in the former Zaire in 1997:

\begin{abstract}
South Africa emerging from apartheid is not the same as Congo emerging from Mobutuism. At least two political differences are worth noting. The South African transition was a compromise between forces for and against apartheid; the Congolese transition is marked by military victory of the anti-Mobutu forces. Whereas the South African transition was worked out mainly through an internal arrangement, with foreign influence limited to an indirect role, the transition in Congo is being worked out through a more direct regional involvement. These differences explain why South African diplomacy failed to achieve its intended objectives over the past few weeks [of mediation]. South African diplomats publicly sought a transition authority led by forces other than Laurent Kabila and the Alliance, and tried to convince Kabila to acquiesce in this. The initiative asked Alliance forces to turn from the brink of victory and sign a compromise! Was this breathtakingly naïve because South African diplomats read the Zaire situation through South African lenses?
\end{abstract}

In a nutshell, then, South Africa rather naïvely sought to achieve a negotiated settlement through the South African model of compromise and the creation of a Government of National Unity between President Mobutu and the rebel AFDL, under the leadership of Laurent Kabila, at a time when the AFDL had already routed Mobutu's forces and were on the outskirts of Kinshasa itself.

\section{In Angola}

South Africa's failure to force a negotiated settlement between Kabila and Mobutu in the DRC in no way prevented the country from making the same mistake in Angola in the 1990s when it tried to negotiate a South African-style Government of National Unity (GNU) between the ruling Popular Movement for the Liberation of Angola (MPLA), under President Eduardo dos Santos, and the rebel UNITA movement under Jonas Savimbi's leadership. On the afternoon of 22 February 2002 Jonas Savimbi's bullet-riddled corpse was put on display by the Angolan Armed Forces (FAA) after a fierce gun battle between UNITA and FAA forces in Moxico province. Shortly after the shock announcement of Savimbi's death, there was more bad news for UNITA when, on 6 March, the death of Savimbi's deputy - General Antonio Dembo - was announced. ${ }^{13}$ Militarily defeated, severely weakened by 
malnutrition and demoralised by the death of their leaders, the remaining UNITA leadership sued for peace. ${ }^{14}$ This was how Angola's long-running civil war ended, not through a GNU-style arrangement. What South Africa's foreign policymakers do not seem to understand is that the political culture and exigencies in South Africa at the time of its democratic transition resulted in all major players adopting mini-max strategies, where compromise was the key. However in countries like Angola and the DRC, where the parties to the conflict believed that they had more to lose from negotiations and were convinced that they could win by force of arms, those exigencies did not exist, resulting in far more zero-sum games being played. In the process, compromise was jettisoned. In Angola, for instance, various attempts at conflict resolution, ranging from regional actors like Presidents Mobutu and Mandela to efforts by the UN, to achieve an inclusive power-sharing arrangement between the MPLA government and UNITA foundered on the all or nothing approach exhibited by both parties. ${ }^{15}$

\section{In Zimbabwe and elsewhere}

Even where the South African experience does have applicable lessons in a given situation, Pretoria's response was misguided. During its tenure on the UN Security Council from 2007 to 2008, Pretoria protected problematic regimes like Burma (Myanmar), Iran, Sudan and Zimbabwe from censure. ${ }^{16}$ The South African argument was that any condemnation or coercive measures adopted would only fuel the respective regime's intransigence. ${ }^{17}$ Rather, South Africa opted for diplomatic engagement. Interestingly enough, this was the same logic which former US Assistant Secretary of State Chester Crocker used to justify his 'constructive engagement' policy with apartheid South Africa in the 1980s. ${ }^{18}$

Former Foreign Minister Dr Nkosazana Dlamini-Zuma summed up this perspective as follows: 'Our own national experience has taught us the value of seeking negotiated solutions to problems, no matter how intractable they may at first seem, and of engaging with all the relevant stakeholders in dialogue. ${ }^{19}$ However, it was South African Prime Minister BJ Vorster, under pressure from London and Washington, who threatened to cut off all support to Salisbury, thereby compelling the recalcitrant Ian Smith to the Lancaster House negotiating table in 1978 and ending his minority-white rule that paved the way for the creation of a democratic Zimbabwe. ${ }^{20}$ It was the fact that sanctions were placed on $90 \%$ of South African exports that compelled the apartheid regime to unban the ANC and engage in negotiations and the creation of a democratic South Africa. ${ }^{21}$ Dr Dlamini-Zuma's perspective of 'national experience', therefore, may relate to the ideological blinkers our foreign policy establishment came to wear, and which became all too evident in the Mbeki years.

Under the Zuma administration there seems to be some positive change to South Africa's foreign policy in this arena. When accepting the letters of credence from Myanmar's ambassador to South Africa, U Tin oo Lwin, President Jacob Zuma pointed out the political problems Myanmar was experiencing and spoke of the need for its speedy resolution. This was interpreted as a rebuke to the military junta in Rangoon. ${ }^{22}$ Moreover, following the renewed house arrest of opposition leader Aung San Suu Kyi, Deputy Minister Ebrahim Ebrahim summoned the Myanmar Ambassador for a dressing down in which he stressed the importance of human rights. ${ }^{23}$ Similarly, President Zuma's state visit to Angola was seen by analysts like 
Dr Siphamandla Zondi of the Institute for Global Dialogue as a means to influence a potentially strong ally for recalcitrant Zimbabwean President Robert Mugabe on the importance of pressuring ZANU-PF into making the necessary political compromises for the stability of Zimbabwe. ${ }^{24}$

\title{
South Africa's ambiguous stance on human rights
}

On a continent noted for the fact that state security (the de facto security of elites) is often purchased at the expense of human security (the security of ordinary citizens), human rights must be the bedrock of any sustainable peace and security framework for the African continent. Moreover, in an increasingly interdependent world where insecurity anywhere threatens security everywhere, South Africa has a vested interest in promoting security among its neighbours. The fact of two million Zimbabweans taking refuge in South Africa brings home this truism. ${ }^{25}$

Following its struggle against the apartheid regime, and in the establishment of its own liberal democratic constitution, many believed that South Africa would promote democratic reform across the continent. Indeed such hope was raised when South Africa became one of the founding signatories of the Rome Statute of 1998, which established the International Criminal Court (ICC). As Director-General of the newly renamed Department of International Relations and Cooperation, Dr Ntsaluba made clear the fundamental changes in international law and South Africa's support for these developments at that time:

\begin{abstract}
Over the past two decades, a radical transformation of international politics has taken place that has resulted in fundamental changes in the international legal order. The importance of international law in enhancing a rule-based international order has considerably extended as international law moved away from its traditional premise of a system of sovereign states towards a more 'constitutional' framework of international society aimed at improving the human condition. Consequently, a proliferation in fields of regulation and judicial organs has taken place. These developments have further enhanced the importance of the key principle of South Africa's strategic foreign policy objective to contribute to the formulation of international law and the enhancement of respect for its provisions. ${ }^{26}$
\end{abstract}

This assessment on the part of the Director-General on the transformation of international law is remarkable. International initiatives such as the Responsibility to Protect, the establishment of the ICC and the fact that tyrants such as Slobodan Milosevic and Charles Taylor cannot hide their murderous actions behind a veneer of sovereignty are all indications that the world is increasingly embracing the concept of human security, with its concomitant notion of individual accountability. For Africa this must be seen as a positive development. For too long, the Amins and Bokassas, the Mobutus and Bashirs, the Taylors and Mugabes have held sway, terrorising whole societies over successive generations. When President Mbeki announced his muchvaunted African Renaissance it was felt that South Africa too could play a key role in the establishment of the rule of law, good governance and accountability on the continent. Unfortunately the vision of an African Renaissance was mere rhetoric and proved to be a cruel mirage in the desert on a continent thirsting for peace and good government. While Mbeki's vision of an African Renaissance was a noble one, it could be said that he underestimated the intransigence of status quo rulers like Mugabe who correctly surmised that developments like NEPAD, with its emphasis 
on good governance, would undermine their own control over the polity. Moreover, Mbeki's ideological pan-Africanist ideology resulted in his wishing to stand in solidarity with other African leaders despite the fact that they served to undermine his own vision of an African renewal by oppressing their fellow African citizens. Thus Mbeki's pan-Africanism directly undermined his vision of an African Renaissance. Reflecting on this issue, Dr Xolela Mangcu examined how Mbeki's foreign policy was suffused with a 'discourse of racial nativism'. He writes, 'In this Manichean world of good and evil we were called upon to be either with other Africans or with whites and the West. Zimbabwe's Robert Mugabe rode not only on the language of racial nativism but also in the knowledge that there were leaders like Mbeki who would protect him in international forums on the account of his race and history'. ${ }^{27}$

Indeed, there were many cases where South Africa in effect supported the status quo. Pretoria appeared on the one hand to bolster leaders who were abusing power with brutal effect, and on the other hand to undermine factions opposing those leaders. As early as 2006, South Africa sought to provide diplomatic cover to Khartoum in the UN Human Rights Council by opposing a resolution critical of Sudan's conduct in Darfur. ${ }^{28}$ Was this also a case of the 'racial nativism' of Mbeki? The following year South Africa, now sitting on the UN Security Council, continued to extend Sudan diplomatic cover, which finally culminated in South Africa's opposition to the ICC indictment against Sudanese President Omar el Bashir. While in effect condoning the state-sponsored violence of the Sudanese government, President Mbeki was prepared to give the rebels in Darfur no quarter and called on the international community to take firm action against them. Indeed in truly Orwellian-speak Mbeki referred to the rebels as 'choosing to engage in violent actions against the innocent people of Darfur'. ${ }^{29}$

A similar pattern was to emerge in Zimbabwe where Pretoria was quick to defend the actions of the ZANU-PF in Harare and even quicker to condemn the political opposition. On 22 November 2008, President Mbeki - the Southern African Development Community (SADC)-appointed mediator — wrote a letter to the opposition Movement for Democratic Change (MDC) leader Morgan Tsvangirai and said:

it may be for whatever reason, you consider our region and continent as being of little consequence to the future of Zimbabwe, believing that others further away, in Western Europe and North America, are of greater importance. In the end, when all is said and done, Zimbabwe [has] to exist in peace and productive collaboration with its neighbours in Southern Africa and the rest of Africa. Realistically, Zimbabwe will never share the same neighbourhood with countries of Western Europe and North America, and therefore secure its success on the basis of friendship with these and contempt for the decisions of its immediate African neighbours. ${ }^{30}$

This message, emanating from a supposedly neutral mediator, was extremely problematic and accounts for the fact that the MDC persevered in replacing Mbeki as mediator. More importantly, it points to the fact that Pretoria had accepted the ZANU-PF characterisation of Mr Tsvangirai as a tool of British/European/Western imperialism.

The question that needs to be posed is why Pretoria sided with authoritarian leaders as opposed to the citizenry in countries like Zimbabwe and Sudan? One answer given to the question was the notion of the solidarity between liberation movements in southern Africa. For instance, the ANC's head of international affairs 
and policy, Mavivi Myakayaka, criticised those in South Africa who wished to see a more critical stance adopted by Pretoria vis-à-vis the Mugabe regime. He stated, 'We can't do that as the ANC. Firstly, we have historical ties with ZANU-PF ... These are our comrades we fought with in the struggle... Our relations have been sealed in blood. ${ }^{31}$

Romantic as this may seem, it is false. During the anti-apartheid struggle in South Africa as well as the struggle against white minority rule in Rhodesia, the ANC was allied with Joshua Nkomo's ZAPU and not ZANU. ${ }^{32}$ If this idea of liberation movement solidarity has any relevance, then the ANC should have been fighting Mugabe's regime since ZANU brutally suppressed ZAPU in the 1980s with the assistance of the North Koreans and killed an estimated 20000 people in Matabeleland. ${ }^{33}$

Others have pointed to the surprisingly disappointing human rights foreign policy of the Mandela administration, which Mbeki was loathe to repeat. In late 1995, President Mandela led a one-man campaign against Nigeria on account of the execution of Ken Saro-Wiwa and the other Ogoni activists. Nigerian President Sani Abacha was unmoved. Africa was embarrassed, and distanced itself from Pretoria's stance, both at the levels of SADC and the AU's predecessor, the Organisation of African Unity (OAU). The Commonwealth vacillated — unable to arrive at a decision which would antagonise such an important country as Nigeria in terms of size and regional influence. By April 1996, South Africa's High Commissioner was back in Abuja while South Africa's ambassador to the UN joined African resistance to a UN resolution that would have appointed an international human rights watchdog over Nigeria. ${ }^{34}$

The lesson, analysts conjecture, that President Mbeki learned from this debacle is that neither Africa nor the world was ready for South African leadership in the human rights realm. Other commentators have taken this further and pointed out that Africanist solidarity would prevent any censure of a fellow African head of state. ${ }^{35}$ While this may certainly have been true in 1995 , this was clearly not the case by 2008 , as the quote at the beginning of this paper by Abdelbagi Jibril makes clear. Indeed, by 2007 African countries like Cameroon, Ghana, Senegal and Zambia were all urging the Human Rights Council to adopt a more assertive position on the Darfur crisis. ${ }^{36}$ Similarly, there was no 'Africanist solidarity' on the issue of Zimbabwe. Former Zambian President Levy Mwanawasa called Zimbabwe a 'regional embarrassment'. Kenyan Prime Minister Raila Odinga went further and labelled Zimbabwe an embarrassment to all Africa. Botswana, meanwhile, summoned Zimbabwe's envoy to complain about the political violence in the country. In response to Mugabe vowing not to give up power even if beaten in an election, Rwandan President Paul Kagame cynically noted, 'For me the question that it raises is why do you even call for elections? ${ }^{37}$

Unfortunately, it was not a Zambia or a Rwanda which had the capability to force Mr Mugabe to the negotiating table and ensure the necessary concessions for a sustainable end to the conflict in Zimbabwe. It was only South Africa that possessed the necessary leverage in economic terms to enforce compliance from Zimbabwe. However, policymakers' mindsets in Pretoria were still caught up in the Nigerian fiasco of the mid-1990s without realising that many on this continent had moved on, creating new realities and new opportunities for peace and security. Therefore, where Pretoria had earlier rushed headlong into intervention, they were now overcautious and thus, ineffectual. Ultimately Pretoria's policy of 'quiet diplomacy' together with 
the ineffectiveness of both SADC and the AU lay at the core of the longevity of Zimbabwe's crisis.

\title{
Africa's hollow peace and security architecture
}

Contrary to successive South African administrations' failings in mediating peace, however, South Africa has played an instrumental role in contributing to the continent's peace and security architecture over the past several years. While this is an effort that needs to be lauded, Pretoria must also be honest in recognising the holes in these structures. One such area in need of attention is post-conflict reconstruction - an important field of endeavour given the phenomenon of return conflicts on the African continent. Another is the need for changes within the SADC Organ on Politics, Defence and Security Co-operation.

\section{NEPAD's Post-Conflict Reconstruction Policy Framework}

Here the importance of the NEPAD Post-Conflict Reconstruction Policy Framework ${ }^{38}$ cannot be over-emphasised. Its true value lies in the fact that it fully embraces the notion of positive peace and therefore is quite holistic in nature and is an integral programmatic part of the AU's approach to post-conflict reconstruction. Indeed the framework states:

\begin{abstract}
Post-conflict reconstruction is understood as a complex system that provides for simultaneous short-, medium- and long-term programmes to prevent disputes from escalating, avoiding a relapse into violent conflict, and to build and consolidate sustainable peace. Post-conflict reconstruction is ultimately aimed at addressing the root causes of a conflict and to lay the foundations for social justice and sustainable peace. Post-conflict reconstruction systems proceed through the broad phases, namely the emergency phase, the transition phase and the development phase; however, they should not be understood as absolute, fixed, time-bound or having clear boundaries. ${ }^{39}$
\end{abstract}

The NEPAD framework ${ }^{40}$ does, however, suffer from certain weaknesses. While it does state that special needs, such as those of women, have to be factored into planning and programming, for instance, there is no commitment to gender mainstreaming and its implications for post-conflict reconstruction policy. ${ }^{41}$ This omission is striking since, as Anderlini and El-Bushra ${ }^{42}$ eloquently argue:
If women are absent from the decision-making processes and if gender perspectives are not integrated in the assessments, planning and implementation, then there is a strong likelihood that women's needs are neglected and that capacities are overlooked. Countries emerging from war, where women often make up the majority of the population, cannot afford to ignore and marginalise their needs and skills.

In this area and others, it is argued, the NEPAD framework is much too wide, with little detail on the mechanisms of implementation. In terms of some practical measures of gender mainstreaming that could be undertaken, Anderlini and ElBushra $^{43}$ do state that:

Women's organizations can take a direct role in reconstruction efforts by bidding for contracts on physical and social reconstruction projects, as well as supporting microfinance projects that are often targeted to women. This will benefit their members and 
provide organizations themselves with the experience of interacting in a business environment, as well as ensuring that the funds reach a broad range of beneficiaries.

Another serious weakness in the NEPAD framework is the lack of sufficient attention placed on war economies. Berdal and Malone ${ }^{44}$ make it clear that the political economy of civil war is a key source of 'protractedness' in many of today's conflicts and remains unchallenged by traditional peace-building approaches. The recent transition from war to negative peace ('the absence of war') in the Democratic Republic of Congo has hardly addressed the prevalent war economy in this vast central African state. During 2002 and 2003, for instance, rival Hema and Lendu militias in the eastern part of the DRC fought for control over the gold mining town of Mongbwalu in Ituri, causing fierce fighting and over 2000 civilian deaths. Numerous other instances demonstrating the inter-relationship between war and resource control can also be cited. ${ }^{45}$ Given the fact that issues of war economy did not feature in the peace agreement, is it any wonder then that fighting still continues in parts of the country and that several commentators have expressed the sentiment that it is likely that the fighting could reignite?

While the NEPAD framework does refer to the need for democracy in postconflict reconstruction, in that it emphasises issues of governance, participation and respect for human rights, the relationship between democracy and conflict is not properly explored. As Khabele Matlosa ${ }^{46}$ notes when referring to Angola's ill-fated 1992 election following the 1991 Bicesse Accords, elections can also exacerbate political violence. This is especially true in a political culture that instils zero-sum games among the participants. ${ }^{47}$

Tim Murithi ${ }^{48}$ has also criticised the NEPAD framework for not providing a clear institutional interface for civil society in post-conflict reconstruction other than to discuss issues at various forums. The active involvement of civil society is often the key for a successful post-conflict reconstruction phase. Indeed, there is a need for greater co-ordination of financial and human resources. Civil society involvement will also assist in enhancing effective and coherent preventive strategies. ${ }^{49}$ This omission on the part of NEPAD, of institutional mechanisms bringing state and non-state actors together, is inexcusable if one considers the amount of work done by scholars in this area. For instance, writing on the need for a more effective liaison between non-governmental organisations (NGOs) and a peacekeeping force, Rocky Williams ${ }^{50}$ of the Institute for Security Studies stated that the following measures can be of assistance:

namely the creation of joint forums at strategic, operational and tactical levels where NGOs and the political and military representatives of the peace force can meet and discuss co-operation; creating a unity of objective between NGOs and the peace force; involving NGOs as early as possible to prevent mistrust from developing; identifying a lead agency (for example, the United Nations High Commissioner for Refugees) to take responsibility for the leadership of the different NGOs within a sector of responsibility; and building trust through the sharing of information between NGOs and the UN peace force in question.

Another area that the NEPAD framework could have paid attention to relates to the threat posed by 'peace spoilers'. The advent of peace does threaten certain belligerents, especially within the context of a war economy. We have seen how the signing of the Good Friday Peace Accords in Northern Ireland resulted in the 
formation of the Real Irish Republican Army (Real IRA) which accused Sinn Fein and the IRA of 'selling out to the British'. Similarly following the signing of the Oslo Peace Accords between Israeli Prime Minister Yitzhak Rabin and Palestinian Liberation Organisation (PLO) Chairman Yasser Arafat, Hamas too challenged the PLO leadership for its compromises and moderate stance. ${ }^{51}$ These 'spoilers' then would seek to undermine prospects for peace at every turn and must be neutralised for peace to thrive. Here, Stephen Stedman ${ }^{52}$ highlights the importance of keeping 'peace spoilers' in check through better intelligence and increased deterrence capabilities in the military component of peace-building missions.

\section{SADC's Organ on Politics, Defence and Security Co-operation}

It is not only NEPAD, however, that is in need of an overhaul in the area of peace and security, but also the SADC Organ on Politics, Defence and Security Cooperation. For the purposes of this paper, three problems will be discussed briefly to highlight how problematic the SADC Organ is as an effective vehicle for peace and security in the sub-region.

First, there is Article 8 (c) of the Protocol, ${ }^{53}$ which stipulates that decisions of the Ministerial Committee shall be taken by consensus. This is problematic. Consider the following scenario: a SADC member state engages in gross human rights violations and hangs on to power by means of fraudulent elections. Should other member states on the Ministerial Committee believe that intervention is needed in that country, the offending country simply votes against such intervention. In this way, one recalcitrant member holds the SADC Organ hostage. As such it is recommended that the SADC Organ follow the example set by the OAU in its latter years: decisions could be reached by consensus minus one.

Second, there is the question of sovereignty. In an increasingly interdependent world where sovereignty is challenged daily, SADC has chosen to interpret sovereignty in an absolute sense. Consider here the following introductory statement to be found in the Organ's Protocol:

Recognising and re-affirming the principles of strict respect for sovereignty, sovereign equality, territorial integrity, political independence, good neighbourliness, interdependence, non-aggression and non-interference in internal affairs of other States. ${ }^{54}$

Issues of sovereignty, territorial integrity and non-interference in the domestic affairs of member states also found their way into the Mutual Defence Pact of SADC. This absolutist notion of sovereignty is extremely problematic if regional integration is to be successful in Southern Africa. According to Ernst Haas ${ }^{55}$ international integration involves, '... the process whereby political actors in several distinct national settings are persuaded to shift their loyalties, expectations and political activities towards a new and larger centre, whose institutions possess or demand jurisdiction over the pre-existing states.' In this way, one of the most fundamental principles of the SADC Organ, that of sovereignty, will undermine its primary objective - that of regional integration at the levels of peace and security in Southern Africa. South Africa needs to play a leading role in steering the debate to embrace expanded and ultimately more realistic notions of sovereignty.

Third, increasingly one gets the impression that the African Standby Force is a 'paper tiger'. Nowhere is this more obvious than in its regional 
incarnation - SADCBRIG. Many of the armed forces in the region agree that tremendous strides have been made in such areas as developing common command and control, a common logistics framework, uniformity of training, compatible armaments, common military doctrine and common defence budgeting - all of which is to benefit SADCBRIG. In reality, however, domestic weaknesses are merely reflected at the sub-regional level. The poor state of South Africa's army is perhaps axiomatic of that of SADC as a whole. At a briefing at the Saldhana military base, ${ }^{56}$ members of South Africa's Parliamentary Portfolio Committee on Defence heard that:

- more than half of the country's 76000 soldiers are medically unfit;

- many of the riflemen and servicemen are regarded as too old for deployment and active service;

- lack of funds means the army can deploy only one operational brigade of 3000 and it is 'impossible' to deploy 19 regular army companies and 23 reserve platoons;

- training has virtually come to a halt. Army reservists, for instance, have not been deployed on training exercises since 1996;

- equipment is in a deplorable state with only 20 out of 168 Olifant tanks and 16 out of 242 Rooikat armoured cars being deployed owing to budget constraints; and

- the South African National Defense Force (SANDF) is seriously top-heavy, with a ratio of one general for every 293 soldiers, compared with a general for every 2000 men in the United States Army.

Given the small number of operational units, soldiers have to deploy twice or thrice a year. To put it differently, the British in Afghanistan, the Americans in Iraq and the French work in a cycle of one-in-six. They have five rotations at home before they go back into the conflict zone. The SANDF is working on a cycle of one-in-three which is neither optimal nor sustainable. To compound matters, inexperienced military skills development members (MSD) are starting to get involved in peace missions. ${ }^{57}$

Under these circumstances of domestic weaknesses how can SADC be a strong actor for peace and security - especially as reflected in the region's powerhouse? For its own sake and for that of the region, Pretoria needs to ensure that its armed forces are professional and effective. Where it fails in this, untenable and embarrassing consequences follow. In the DRC, South African troops had the dubious reputation of having the most number of rape charges levelled at them. ${ }^{58}$ In Darfur, Janjaweed rag-tag militias successfully ambushed South African troops. ${ }^{59}$

It should here be noted, however, that there is currently an attempt to strengthen the SANDF through the South African Army's Vision 2020 programme which seeks to build a small, mobile, highly-skilled, well-equipped professional force and that these moves at the national level are being complemented by serious efforts to operationalise the African Standby Force. ${ }^{60}$

\section{Conclusion}

South Africa's contribution to peace and security on the African continent has been disappointing for the most part. There certainly have been attempts at peace-making and peacekeeping across the continent, which need to be lauded. At the same time 
Pretoria's failings in this arena compels one to critically examine its approach to mediation, human rights, holistic peace-building and strengthening security forces.

\section{Mediation}

Unfortunately where Pretoria looks at a conflict through it owns tinted lenses Codesa, Kempton Park and Truth and Reconciliation - failure will forever dog its attempts at peace-making. South Africa must instead begin to look at each conflict on its own terms and understand the players in their own context. Peace-making attempts are bound to fail where these efforts are seen to bolster the status quo as in Zimbabwe, or where it takes the form of an elite compact as in the Democratic Republic of Congo. In essence, peace without justice, whether in Darfur or Zimbabwe, is bound to flounder. Moreover, where the peace-maker is seen to be partial towards one party, neutrality is lost and the mediator loses credibility. Such was the case of former President Mbeki who was eager to lambaste the opposition MDC but not Mugabe, eager to criticise the Darfur rebels but not Bashir. For the mediation effort to succeed, the credibility and hence the neutrality of the mediator is paramount.

\section{Human rights}

Peace and justice, in turn, leads us to the thorny question of human rights, which must become the foundation stone of sustainable security for the African continent. For too long Africa's security architecture was based on the concept of sovereignty. In an increasingly interdependent world, however, insecurity anywhere threatens security everywhere. Sovereignty as a concept, therefore, has become increasingly debased. In reality Africa has experienced not the sovereignty of the state but that of state elites. For far too long structures like the Organization of African Unity and now the African Union privileged the security of the Bokassas and Bashirs, the Mobutus and Mugabes over the human security of Africa's 800 million citizens.

Post-apartheid South Africa can and should be playing a key role in defending the human rights of Africa's citizens both on moral grounds and in its own enlightened self-interest. Morally, the ruling ANC was the beneficiary of a global anti-apartheid movement. Moreover, apartheid destabilisation resulted in the death and/or maiming of millions of this region's citizens. It is therefore morally incumbent upon Pretoria to promote the human security of this region's citizens. From an enlightened national self-interest perspective, war in one country means refugees in another. This is seen most graphically in the masses of Zimbabweans taking refuge within South Africa's own borders. It is therefore in South Africa's own interests that our neighbouring states are stable and secure. This stability and security, however, would only materialise if human rights are the bedrock on which state institutions are built.

This, in turn, raises the issue of how South Africa could pursue the human rights agenda without being isolated as during the Ken Saro-Wiwa affair. I agree with those who would argue that South Africa should not aggressively push the human rights agenda, thereby risking confrontation and isolation within Africa. At the same time, countries like Sudan and Zimbabwe illustrate the danger of doing nothing or very little to advance human rights which must be the bedrock of security. In my view the most politically expedient way to advance the cause of human rights on the continent 
would be two-fold: First, to empower African civil society — not necessarily through the structures of the South African state but via South African civil society; and second, to support those states on the African continent pushing for greater democratic accountability. As was pointed out in this paper, Cameroon, Ghana, Senegal and Zambia all urged the UN Human Rights Council to adopt a more assertive position on the Darfur crisis. Instead South Africa strengthened its bilateral ties with Khartoum, criticised the rebels, allowed President Bashir to pay a state visit to South Africa and attempted to provide diplomatic cover to Sudan. ${ }^{61}$ Similarly on Zimbabwe, governments in Zambia, Kenya, Rwanda and Botswana were all critical of the Harare regime. Instead of supporting these states, Mbeki preferred to censure the democratic opposition while protecting Zimbabwe from international censure. One of the most welcome breaks in the current South African mediation of the Zimbabwean stand-off is President Zuma's move to stress the impartial nature of South African mediation. He recently noted, 'We cannot and will not side with any one of the parties to the exclusion of others'. ${ }^{62}$ At the same time, there is reason to doubt whether measures such as these constitute a decisive break from the foreign policy of the Mbeki years. Dr Zondi has warned that one should not expect a 'Zuma Doctrine', in that President Zuma follows the consensual leadership tradition of the ANC. ${ }^{63}$ If this assessment proves correct, then South African foreign policy will be characterised more by continuity than change - to the detriment of peace and security on the African continent.

\section{Holistic peace-building}

Pretoria also needs to approach peace and security on the African continent in more holistic terms. In practice this would mean that peacekeeping and other military measures such as training and security sector reform are bound to fail if uncoupled from broader state-building initiatives. Thus in the DRC, the South African National Defence Force is assisting in the training of Congolese troops within the structural confines of a predatory state where the very troops being trained have been accused of the most vicious crimes against its citizens. ${ }^{64}$ On the other hand, the Zuma administration has in Sudan continued with President Mbeki's initiatives in support of state building, contributing to public administration and judicial capacity building. ${ }^{65}$ Another positive development is that the Zuma administration, after some procrastination, has also come out clearly in support of the International Criminal Court in its indictment of Sudanese President Bashir, thereby acknowledging its international responsibility under the Rome Statutes. ${ }^{66}$

\section{Strengthening security forces}

South Africa's peacekeeping troops will continue to suffer setbacks as in Darfur if the state of its armed forces remains shoddy and ill-disciplined. Such domestic weaknesses in the SANDF will also not strengthen the African Standby Force. It is in South Africa's and Africa's own interest for Pretoria to expend the necessary resources to create a professional armed force.

If South Africa is serious about promoting a peaceful and prosperous African continent then it must start fixing Africa's hollow peace and security architecture. The NEPAD Post-Conflict Reconstruction Framework hardly deals with issues of war economies or responding to 'peace spoilers'. The moribund SADC Organ, 
meanwhile, continues to be trapped in inaction by archaic rules such as the demand that decisions be arrived at by consensus. Fixing Africa's peace and security architecture is crucial to creating a peace that is less reactive and more preventive in character.

\section{Acknowledgements}

An earlier version of this paper was presented at the conference 'South Africa in the world: A post-transition foreign policy', hosted by the South African Institute of International Affairs, South Africa, London, 22 May 2009.

\section{Notes on contributor}

Professor Hussein Solomon lectures in the Department of Political Sciences, University of Pretoria and is also a Research Associate of the South African Institute of International Affairs. Currently he is also Visiting Fellow of the MacKinder Programme for the Study of Long-Wave Events at the London School of Economic and Political Science.

\section{Notes}

1. Mandela N, 'South Africa's future foreign policy', Foreign Affairs, 72, 5, pp. 87-8

2. Quoted in Nathan L, 'Explaining South Africa's position on Sudan and Darfur', paper presented to the Royal Institute of International Affairs, Chatham House, London, 12 February 2008, <www.chathamhouse.org.uk > (accessed 4 April 2009).

3. King A, 'Key note address', paper delivered to the Seminar on the Image of the United Nations in South Africa, co-hosted by the UN Department of Public Information and the Centre for Southern African Studies, University of the Western Cape, Somerset-West, 8 February 1994, p. 3.

4. South African Institute of International Affairs, 'South Africa in Africa: An assessment', South African Foreign Policy Monitor, March-April 2008, p. 2.

5. Schoeman M \& C Alden, 'The hegemon that wasn't: South Africa's foreign policy towards Zimbabwe', Strategic Review of Southern Africa, May 2003, p. 2.

6. Mandela N, op. cit., p. 87.

7. Department of Foreign Affairs, 'Overview of the Strategic Priorities of the Department of Foreign Affairs for the Period 2008-2011', Pretoria, pp. 6-8.

8. Matlosa K, 'Democracy and conflict resolution in Africa: Challenge for post-conflict reconstruction', Conflict Trends, 1, 2006, p. 12.

9. Habib A, 'South Africa's foreign policy: Hegemonic aspirations, neoliberal orientations and global transformation', 2008, p. 7, <www.giga-hamburg.de/english/content/rpn/ conferences/habib.pdf $>$ (accessed 20 April 2009).

10. South African Institute of International Affairs, 2008, op. cit., p. 2.

11. Ibid., p. 3 .

12. Weekly Mail \& Guardian, 'Naïve South Africa must not adopt missionary position', 29 May 2007.

13. IRIN News, 'Weakened UNITA may cease hostilities', 6 March 2002, < http://www. irinnews.org/Report.aspx?ReportId=30619> (accessed 16 August 2002).

14. Shortly after the death of UNITA leader Jonas Savimbi and his Deputy Admiral Dembo, the remaining UNITA leadership realised that they were in a weakened military and political position vis-à-vis the MPLA government. Moreover, with the diminished foreign support the war could not be further prosecuted and UNITA opted to surrender. To read more on this please see Solomon H, Angola: A Case Study of Aggression, Avarice and Anguish, FAST Country Risk Profile. Berne: Swiss Peace Foundation, 2000.

15. Solomon H, 'From New York to Lusaka and beyond: Angola's tortuous road to peace', Africa Insight, 32, 4, 2000, p. 37.

16. VOA News.com, 'South Africa unrepentant over UN Security Council role', 20 February 2009, < http://www1.voanews.com/english/news/a-13-2009-02-20-voa23-68712827.html> (accessed 14 April 2010). 
17. Ibid.

18. Coady A \& H Solomon, 'Deconstructing constructive engagement: Examining Mbeki's South African foreign policy towards Zimbabwe', World Affairs, 13, 1, 2009, p. 69.

19. Quoted in Nathan L, op. cit.

20. Hutson HPW, Rhodesia - Ending an Era. London: Springwood Books, 1978, p. 138.

21. Geldenhuys D, 'Ten crises in South Africa's international relations', International Affairs Bulletin, 13, 3, 1989, p. 93.

22. The Citizen, 'Myanmar can learn from South Africa', 6 May 2010, p. 3.

23. United Nations Development Programme, 'Is Zuma's foreign policy a change of style or substance?', United Nations Development Programme: South Africa, <http:// www.undp.org.za/index.php/democratic-governance-news/232-is-zumas-foreign-policy> (accessed 5 May 2010).

24. Ibid., p. 2.

25. 'Desperate Zimbabweans Head South', IWPR Institute for War and Peace Reporting, ZIM issue 56, 11 April 2008, <http://www.iwpr.net/report-news/desperate-zimbabweanshead-south $>$ (accessed 11 June 2010).

26. Department of Foreign Affairs, op. cit., pp. 6-8.

27. Xolela Mangcu, 'A new foreign policy for Jacob Zuma's South Africa', The Brookings Institution, 20 July 2009, p. 1, < http://www.brookings.edu/opinions/2009/0720_south_ africa_mangcu.aspx?p $=1>$.

28. Nathan L, op. cit.

29. Ibid., p. 2.

30. Ankomah B, 'Baffour's beefs', New African, No. 483, April 2009, p. 8; Weekly Mail \& Guardian, 'Naïve South Africa must not adopt missionary position', 29 May 2007.

31. Quoted in Schoeman M \& C Alden, op. cit., p. 2.

32. South African Institute of International Affairs, 'Zimbabwe is the new Bantustan', South African Foreign Policy Monitor, January-February 2007, p. 1.

33. Ibid; Solomon $\mathrm{H}$, 'Ten principles of best practice engagement for Africa and South Africa', in Southall R (ed.) South Africa's Role in Conflict Resolution and Peacemaking in Africa. Cape Town: Nelson Mandela Foundation and Human Sciences Research Council Press, 2006, p. 116; Talbott S, 'Zimbabwe: Shadows and lies, recollections of Robert Mugabe', PBS Frontline World, < http://www.pbs.org/frontlineworld/stories/zimbabwe5 04/profile.html $>$ (accessed 4 May 2010).

34. Bell P, 'Steering an erratic course through foreign waters', Africa Today, 3, 2, 1997, p. 16.

35. Solomon H, 2006, op. cit., p. 116.

36. Nathan L, op. cit.

37. Quoted in Solomon H, 'Zimbabwe: God will decide', Eurasia Critic Magazine, August 2008 , p. 39.

38. New Partnership for Africa's Development, 'African Post-Conflict Reconstruction Policy Framework', NEPAD Secretariat, Governance, Peace and Security Programme, Midrand, South Africa.

39. Ibid., p. 3 .

40. Ibid., p. 23.

41. Murithi T, 'The AU/NEPAD post-conflict reconstruction policy: An analysis', Conflict Trends, 1, 2006, p. 19.

42. Anderlini SN \& J El-Bushra, 'Post-Conflict Reconstruction', 2005, p. 61, $<$ www.huntalternatives.org/download/39_post_conflict.pdf > (accessed 27 April 2009).

43. Ibid., p. 62 .

44. Berdal M and DM Malone, Greed and Grievance: Economic Agendas in Civil Wars. London: Lynne Rienner, 2000, p. 2.

45. Solomon H, S Kelly \& I Motsi, Towards Sustainable Peace in the Democratic Republic of the Congo, Centre for International Political Studies, University of Pretoria, Pretoria, 2008 , p. 41.

46. Matlosa, op. cit., p. 14.

47. Ballentine $\mathrm{K} \& \mathrm{G}$ Nitzschke, 'The political economy of civil war and conflict transformation', in Fischer M \& B Schmelzle (eds), Transforming War Economies: Dilemmas and Strategies. Berlin: Berghof Research Centre for Constructive Conflict Management, 2005, pp. 11-35. 
48. Murithi T, op. cit., p. 19.

49. Ryan S, 'Preventive diplomacy, conflict prevention and ethnic conflict', in Carment D \& $\mathrm{P}$ James (eds) Peace in the Midst of Wars: Preventing and Managing Ethnic Conflicts. Columbia, SC: University of South Carolina Press, p. 88.

50. Williams R, 'Peace operations and the South African armed forces: Prospects and challenges', Strategic Review for Southern Africa, 12, 2, 1995, pp. 104-5.

51. Solomon H, 2006, op. cit., p. 116.

52. Stedman SJ, 'International implementation of peace agreements in civil wars: Findings from a study of sixteen cases', in Crocker CA, FO Hampson \& P Aall (eds), Turbulent Peace: The Challenges of Managing International Conflict. Washington, DC: United States Institute of Peace Press, 2001.

53. SADC, 'Protocol on Politics, Defence and Security Cooperation'. Gaborone, Botswana: SADC, p. 11.

54. Ibid., p. 2.

55. Haas EB, The Uniting of Europe: Political, Social and Economic Forces 1950-1957. Stanford, CA: Stanford University Press, 1958, p. 16.

56. Le May J, 'Nearly half of SA army not fit for combat', The Independent on Saturday, 13 July 2002, < http://www.independentonsaturday.co.za/index.php?fSectionId =\&fArticle Id $=$ ct20020713233046795S650627 >.

57. Engelbrecht L, 'Ban asks for more SA peacekeeping support', defenceWeb, 26 February 2009, < http://www.defenceweb.co.za/index.php?option $=$ com_content\&view $=$ article $\&$ id $=$ $1182 \&$ catid $=55:$ SANDF\&Itemid $=108>$.

58. 'Ambush in Sudan', Department of Defence, 5 July 2006, < http://www.dod.mil.za/ media/media 2006/media_5jul06no.2.htm > (accessed 5 May 2010).

59. 'SANDF - rape in the DRC', The Star, 8 November 2008, < http://www.thestar.co.za/ index.php?fSectionID-129\&fArticleId $=2146949>$ (accessed 5 May 2010).

60. See Institute for Security Studies (ISS), South African Army Vision 2020, Volumes 1 and 2, Pretoria: ISS, 2008.

61. South Africa extends Diplomatic Cover to Bashir, Nathan L, 'Explaining South Africa's Position on Sudan and Darfur', Transcript from conference on this subject held at Chatham House, London, 12 February 2008, <www.cmi.no/sudan/doc/?id=934> (accessed 12 June 2010).

62. Voice of America, 'South African president promises impartiality in mediating Zimbabwe political crisis', 13 April 2010, <www1.voanews.com/zimbmabwe/news/politics/SouthAfrican-President-Zuma-Says $>$ (accessed 29 April 2010).

63. United Nations Development Programme, op. cit., p. 1.

64. SA Training Congolese soldiers in the DRC, The Citizen, 'SANDF peacekeeping ops extended', The Citizen, 23 March 2006, <http://www.citizen.co.za/index/article.aspx? $\mathrm{pDesc}=14943,1,22>$ (accessed 8 June 2010).

65. Statebuilding in Sudan, Mashabane MN, Transcript of Minister Maite Nkoana Mashabane's press comments upon conclusion of the Courtesy call on President of Government of Southern Sudan, Salva Kirr Mayardit in Juba, South Sudan, 17 September 2009, Department of International Relations and Cooperation, Republic of South Africa, <http://www.dfa.gov.za/docs/speeches/2009/mash0917.html > (accessed 8 June 2010).

66. Interview with Dr John Yoh, Government of Southern Sudan Liaison Office, Pretoria, 12 March 2010. 